ISSN 2598-7933 (online); 2598-7941 (cetak)

Vol. 2 No. 1 (2019): 193-223, DOI: 10.22437/ujh.2.1.193-223

Ulasan Tokoh dan Pemikiran Hukum

\title{
Biomijuridika: Pemikiran Ilmu Hukum Pidana Berketuhanan dari Barda Nawawi Arief
}

\author{
Muhammad Rustamaji \\ Fakultas Hukum Universitas Sebelas Maret \\ hatchi_ajie@yahoo.com
}

\begin{abstract}
This article discusses the legal thought from Barda Nawawi Arief, named biomijuridika. The concept of biomijuridika is actually an invitation for legal learner to reflect on whether the life of law and the development of law in Indonesia are secular. If jurisprudence contains in it the science of "regulating or arranging", Barda questioned is not "God Most Regulating and Arranging", and therefore the law must also be in accordance with God's teachings. Therefore according to Barda, legal education and legal science in Indonesia should not be secular. Consequently, legal education and national law must also explore and examine the law of the One Godhead. This article shows that in the Indonesian context, the biomijuridika of Barda are actually in line with the Pancasila as the state foundation. On the basis of Pancasila, the life of the nation and state of Indonesia must be based on the Pancasila, which in the life of the law means must, one of them, be based on the One Godhead. However, the legal thought of biomijuridika from Barda still seems to leave a discourse space that seems to have not been answered thoroughly, namely when this concept was proposed as one of the alternative models of legal reform especially in the field of criminal law. Such criticism in particular can be examined in the facets of the development of theoretical and practical law.
\end{abstract}

Keywords: Barda Nawawi Arief; biomijuridika; integral-contextual 


\section{Muhammad Rustamaji}

\section{Abstrak}

Artikel ini membahas pemikiran hukum dari Barda Nawawi Arief yang diberi nama biomijuridika. Konsep biomijuridika sejatinya sebuah ajakan bagi pembelajar hukum untuk merenung tentang apakah kehidupan berhukum dan pengembangan hukum di Indonesia bersifat sekuler. Jika ilmu hukum mengandung di dalamnya ilmu "mengatur atau menata", Barda mempertanyakan bukankah "Tuhan Maha Mengatur dan Maha Menata”, dan karenanya hukum pun mesti sesuai dengan ajaran Tuhan. Oleh karenanya menurut Barda pendidikan hukum dan ilmu hukum di Indonesia seharusnya tidak bersifat sekuler. Konsekuensinya, pendidikan tinggi hukum dan ilmu hukum nasional harus juga menggali dan mengkaji ilmu hukum berketuhanan Yang Maha Esa. Artikel ini menunjukkan bahwa dalam konteks Indonesia, biomijuridika dari Barda sesungguhnya sejalan dengan dasar negara Pancasila. Dengan dasar negara Pancasila, maka kehidupan berbangsa dan bernegara Indonesia mesti didasarkan pada Pancasila, yang dalam kehidupan berhukum berarti mesti, salah satunya, didasarkan pada "Ketuhanan Yang Maha Esa". Namun demikian, pemikiran hukum biomijuridika dari Barda tampaknya masih menyisakan ruang diskursus yang agaknya belum dijawab dengan tuntas, yaitu ketika konsep ini diajukan sebagai salah satu model alternatif pembaruan hukum utamanya pada bidang hukum pidana. Kritik demikian khususnya dapat dicermati pada faset pengembanan hukum teoretis dan pengembanan hukum praktis.

Kata Kunci: Barda Nawawi Arief; biomijuridika; integral-kontekstual

\section{A. Pendahuluan}

Artikel ini mengulas pemikiran hukum biomijuridika dari Barda Nawawi Arief. Sebagai tokoh hukum pidana Indonesia, nama Barda Nawawi Arief tentu sudah tidak asing bagi penstudi hukum. Keterlibatannya dalam upaya pembaruan hukum pidana di Indonesia bisa jadi yang menyebabkan nama Barda menjadi sangat populer bagi penstudi hukum khususnya bidang pidana. Namun demikian, pemikiran beliau tentang biomijuridika dalam pembaruan ilmu hukum pidana, yang sesungguhnya sangat unik dari segi istilah, bisa jadi masih terasa asing bagi penstudi hukum. Hal demikian dapat dipahami 
setidaknya karena dua faktor. Pertama, peristilahan yang kemudian menandai sebuah pemikiran pembaruan ilmu hukum pidana yang tidak sekuler tersebut memang baru disampaikan oleh Barda dalam buku Pembangunan Sistem Hukum Nasional (Indonesia) pada tahun 2012. ${ }^{1}$ Kedua, pemikiran mengenai biomijuridika demikian memang tidak secara eksploratif lebih diulas, misalnya jika diperbandingkan dengan kajian mengenai asas legalitas yang acapkali diidentikkan dengan kajian-kajian Barda selama ini.

Sebagai sebuah penanda atas suatu pemikiran di sektor hukum pidana, biomijuridika tentu mengundang banyak pertanyaan dari berbagai kalangan. Bagaimana pemikiran demikian muncul, apa gagasan yang melatarinya, bagaimana ia berbagi ruang dan berkorelasi dengan beragam literasi yang saat ini sudah sedemikian pesat perkembangannya, serta apa urgensi dan relevansinya terutama bagi pembaruan hukum pidana Indonesia, adalah beberapa pertanyaan penting yang dapat diajukan untuk menyambut sebuah pemikiran yang dikemukakan oleh seorang tokoh hukum.

Artikel ini mencoba mengulas dan menjawab beberapa pertanyaan tersebut. Ulasan mengenai biomijuridika demikian diharapkan menjadi pemantik diskursus atas kondisi kekinian pendidikan tinggi hukum hingga dinamika perkembangan pemikiran global mengenai arah pembaruan ilmu hukum. Dua bentangan kajian dari ranah pendidikan tinggi hukum hingga perkembangan pemikiran global inilah yang selanjutnya menjadi titik pijak atas lontaran kritik sehingga memunculkan gagasan mengenai biomijurika dimaksud.

\section{B. Barda Nawawi Arief: Perjalanan Hidup dan Buah Pikir}

Barda Nawawi Arief lahir di Cirebon, 23 Januari 1943. Ia menyelesaikan pendidikan Sekolah Rakyat (S.R) di tempat kelahirannya, 1956. Sekolah menengahnya ditempuh di Surakarta: SMP Bagian B selesai 1959 dan SMA B selesai 1962. Pendidikan tingginya di bidang ilmu hukum diperoleh dari Universitas Diponegoro, Semarang untuk tingkat

1 Barda Nawawi Arief, Pembangunan Sistem Hukum Nasional (Indonesia) (Semarang: Pustaka Magister, 2012). 
sarjana (S-1) tahun 1968 dan Universitas Padjadjaran, Bandung untuk tingkat doktoral (S-3) tahun $1986 .^{2}$

Dalam karirnya, Barda mengabdikan diri pada Universitas Diponegoro. Di perguruan tinggi ini, Barda pernah menjadi Dekan Fakultas Hukum dan Ketua Program Magister Ilmu Hukum. Sebagai sosok akademisi yang konsisten dengan bidang kajian keilmuan di bidang hukum pidana, Barda kemudian menjadi guru besar hukum pidana pada 1993.

Di luar lingkungan Universitas Diponegoro, Barda juga pernah mengajar di banyak universitas, terutama untuk pendidikan pascasarjana (S-2 dan S-3). Beberapa kampus di mana beliau pernah mengajar ialah, Universitas Indonesia, Universitas Gadjah Mada, Universitas Padjadjaran, Universitas Sebelas Maret, Universitas Islam Indonesia, Universitas Islam Bandung, Universitas Sumatera Utara, Universitas Lampung, Universitas Bengkulu, Universitas Udayana, Universitas Tanjungpura, dan masih banyak lainnya.

Selain dikenal sebagai pendidik di berbagai perguruan tinggi di Indonesia, baik negeri maupun swasta, Barda juga merupakan salah satu penyusun Rancangan Undang Undang Kitab Undang-undang Hukum Pidana (RUU KUHP). Ia pernah menjadi anggota tim pakar hukum dalam berbagai departemen dan lembaga negara. Berbagai artikel ilmiah sudah dihasilkan dari tangan dinginnya, baik yang diterbitkan dalam bentuk buku, artikel lepas, maupun artikel jurnal di dalam maupun di luar negeri.

Beberapa karya dalam bentuk buku memberikan gambaran secara utuh bagi pembacanya mengenai bagaimana seharusnya ilmu hukum pidana nasional diperbarui dan dikembangkan. Di antara karya ilmiah Barda dalam format buku adalah: Perbandingan Hukum Pidana; Teori dan Kebijakan Pidana; Bunga Rampai Hukum Pidana; Kebijakan Legislatif dalam Penanggulangan Kejahatan dengan Pidana Penjara; Pembaruan Hukum Pidana dalam Perspektif Kajian Perbandingan; Masalah Penegakan Hukum dan Kebijakan Hukum Pidana dalam Penanggulangan Kejahatan; Delik Agama dan Blasphemy; RKUHP:

2 https://bardanawawi.wordpress.com/riwayat-hidup/, diakses 20/7/2019. 
Sebuah Rekonstruksi; Mediasi Penal, Penyelesaian Perkara di Luar Pengadilan; Pembangunan Sistem Hukum Nasional (Indonesia); Beberapa Aspek Pengembangan Ilmu Hukum Pidana (Menyongsong Generasi Baru Hukum Pidana Indonesia); dan setidaknya ada dua puluh dua judul buku yang sudah diterbitkan.

\section{Sebuah Pemikiran Bernama Biomijuridika}

Secara konseptual, biomijuridika sebagai suatu pemikiran ilmu hukum pidana yang berketuhanan Yang Maha Esa pertama kali diketahui jejak teksnya pada pidato pengukuhan Barda Nawawi Arief sebagai guru besar ilmu hukum pidana Fakultas Hukum Universitas Diponegoro pada 25 Juni 1994. Namun demikian, pada saat itu memang belum digunakan istilah biomijuridika.

Guna mengulas berbagai pertanyaan dimaksud, berikut disajikan skema yang menjadi alur kemunculan pemikiran yang disematkan tanda dengan istilah biomijuridika tersebut.

Gambar 1. Skema Biomijuridika

\begin{tabular}{|c|c|c|c|}
\hline $\begin{array}{c}\text { Kritik atas Professional Law Education } \\
\text { yang menegasikan Tugas Keilmuan } \\
\text { dan Tugas Nasional }\end{array}$ \\
$\begin{array}{c}\text { Normatieve Maatschappij Wetenschap } \\
\text { Indonesia } \\
\text { (Pancasila) }\end{array}$
\end{tabular}

Berdasarkan gambar 1, kemunculan pemikiran biomijuridika merupakan rangkaian dari kritik Barda terhadap pendidikan tinggi hukum yang hanya berfokus dalam menyelenggarakan pendidikan hukum profesional (professional law education). Barda dalam pidato pengukuhan guru besarnya mengungkapkan bahwa gencarnya sorotan dan kritik masyarakat terhadap menurunnya kualitas penegakan hukum pidana, jelas tidak ditujukan pada merosotnya kemampuan dan kematangan intelektual menguasai norma-norma hukum pidana, akan tetapi justru ditujukan pada terjadinya kemerosotan atau erosi nilai. Jadi tampaknya ketidakmatangan nilai atau kejiwaan 


\section{Muhammad Rustamaji}

inilah yang terutama menjadi keprihatinan masyarakat, dan seyogianya juga menjadi keprihatinan semua lembaga pendidikan tinggi hukum. ${ }^{3}$ Pada kondisi demikian, tanpa disadari pendidikan tinggi hukum rupa-rupanya kurang memberikan perhatian yang sama pada "tugas keilmuan (konsepsional akademik)" dan "tugas nasional”. Usaha untuk menghasilkan sarjana hukum yang memiliki kemampuan akademik dan kemampuan profesional termasuk kemahiran serta keterampilan hukum dalam hukum positif, dalam pandangan Barda tidak boleh meninggalkan kewajiban untuk mengemban tugas pengkajian dan pengembangan serta pembaruan ilmu hukum nasional.

Dua tugas yang terakhir disebut, merupakan tantangan yang harus dijawab dalam mengisi dan memberikan sumbangan konseptual bagi terciptanya pembaruan ilmu hukum nasional, khususnya ilmu hukum pidana Indonesia. Barda juga menegaskan bahwa dalam situasi sedang menghadapi masalah besar di bidang pembaruan hukum pidana, sangatlah dirasakan janggal apabila di dalam pendidikan tinggi hukum justru tidak ada kajian khusus mengenai "pembaruan hukum pidana”. Kritik demikian tidak berarti bahwa secara kelembagaan pendidikan tinggi hukum tidak terlibat dalam permasalahan pembaruan hukum, akan tetapi ragam kegiatan pembaruan yang telah dilakukan masih bersifat individual, insidental dan temporal. Akibatnya, tidak sedikit berbagai ide-ide pembaruan hukum pidana tidak sampai kepada para mahasiswa. Tidak sedikit pula beragam bahan-bahan pembaruan hukum pidana hanya berhenti setelah seminar maupun lokakarya selesai digelar.

Keberlanjutan pengembanan tugas pembaruan ilmu hukum oleh pendidikan tinggi hukum sebagai tugas nasional sudah semestinya menjadi kegiatan berlanjut (sustainable activity) secara kelembagaan. Titik berat mengenai hal-hal yang secara langsung maupun tidak langsung guna meningkatkan pembaruan dan pembinaan hukum nasional oleh lembaga pendidikan hukum bahkan ditegaskan menja-

3 Barda Nawawi Arief, Beberapa Aspek Pengembangan Ilmu Hukum Pidana (Menyongsong Generasi Baru Hukum Pidana Indonesia) (Semarang: Pustaka Magister, 2011), hlm. 59-60. 
di salah satu kesimpulan Seminar Hukum Nasional ke-3 pada 1974 di Surabaya. Pembaruan dan pembinaan hukum nasional dalam hal ini berkait erat dengan hakikat ilmu hukum sebagai normatieve maatschappij wetenschap, yakni ilmu normatif tentang hubungan kemasyarakatan. Dengan lain perkataan, Barda berpandangan bahwa ilmu hukum merupakan ilmu normatif (das sollen) tentang kenyataan $(\text { das sein })^{4}$.

Berdasarkan konsepsi normatieve maatschappij wetenschap demikian, maka permasalahan pembaruan ilmu hukum pada konteks Indonesia, yaitu bagaimana menggeser orientasi konsep ilmu hukum sebelum kemerdekaan, ke arah ilmu hukum setelah kemerdekaan. Oleh karenanya, ketika tatanan kehidupan berbangsa pasca kemerdekaan Indonesia adalah tatanan berkehidupan berdasarkan Pancasila, maka ilmu hukum yang dikembangkan pada hakikatnya membangun konsep tatanan yang berorientasi nilai Pancasila. Dengan lain perkataan, Barda ingin mengetengahkan bahwa jika sebelumnya dipertanyakan mengenai ilmu hukum nasional yang diharapkan dapat diwujudkan sebagai pengejawantahan tatanan kehidupan berbangsa, maka kiranya perlu disimak pandangan Barda mengenai upaya pembangunan ilmu hukum nasional tersebut. Barda mengemukakan bahwa apabila "tatanan berkehidupan kebangsaan" yang dicitacitakan bangsa Indonesia adalah tatanan berdasarkan Pancasila, maka ilmu hukum Indonesia adalah ilmu mengenai tatanan berkehidupan kebangsaan berdasarkan Pancasila. Ini berarti membangun sistem hukum nasional pada hakikatnya membangun konsep-konsep tatanan yang berorientasi pada nilai/paradigma Pancasila, yaitu paradigma ketuhanan (moral-religius), paradigma kemanusiaan, paradigma kebangsaan (persatuan/kepentingan umum), paradigma kerakyatan/demokrasi, dan paradigma keadilan sosial. Dapat pula dikatakan secara singkat, bahwa ilmu hukum nasional (ilmu hukum Pancasila) adalah ilmu hukum yang berorientasi pada tiga pilar/ nilai keseimbangan Pancasila, yaitu: ilmu hukum bernilai/berpilar/ berorientasi ketuhanan (bermoral religius), ilmu hukum bernilai/

4 Arief, Pembangunan Sistem Hukum Nasional, hlm. 27. 
berpilar/berorientasi kemanusiaan (humanistik), dan ilmu hukum bernilai/berpilar/berorientasi kemasyarakatan (nasionalistik, demokratik, berkeadilan sosial). Ini berarti ilmu hukum yang tidak berorientasi pada ketiga pilar/nilai/pendekatan/jiwa (ruh) demikian, bukan merupakan ilmu hukum nasional. ${ }^{5}$

Mencermati pandangan Barda demikian, maka ketika menyimak kembali perjalanan sejarah perjuangan bangsa, seluruh elemen bangsa Indonesia sejatinya telah dipererat persatuannya dengan adanya kesepakatan pada 1 Juni 1945 untuk menggunakan Pancasila sebagai ideologi pemersatu bangsa. Sebagai ideologi, kehadiran Pancasila merupakan solusi dari konflik antara kelompok agama dan nasionalis. Dalam hal ini, Pancasila telah mampu berfungsi sebagai pemersatu bangsa Indonesia yang majemuk. Pancasila sebagai suatu ideologi merupakan nilai-nilai filosofis asli bangsa Indonesia yang diambil dari warisan nilai moral, etika dan budaya nenek moyang bangsa Indonesia. Pancasila mengandung nilai-nilai yang dicitacitakan bersama bangsa Indonesia untuk diwujudkan. Pancasila sebagai ideologi memiliki konsepsi tentang masyarakat yang ideal, masyarakat yang paling baik bagi manusia Indonesia. ${ }^{6}$

Ideologi memberi setiap elemen bangsa hal-hal ideal untuk diyakini, tujuan untuk diusahakan dan alasan untuk diperjuangkan. Fungsi penting lain dari ideologi adalah membentuk identitas kelompok yang majemuk atau bangsa. Ideologi memiliki kecenderungan untuk "memisahkan" kita (in-group) dan mereka (out-group). Dengan demikian ideologi berfungsi mempersatukan. ${ }^{7}$

Apabila dibandingkan dengan agama, agama juga berfungsi mempersatukan manusia dari berbagai kalangan yang majemuk dengan berbagai pandangan hidupnya masing-masing, bahkan

5 Arief, Pembangunan Sistem Hukum Nasional, hlm. 30-32.

6 Muhammad Rustamaji, Pembaruan Hukum terhadap Formulasi Asas Praduga Tidak Bersalah dalam Konteks Keindonesiaan (Kajian Norma dan Nilai), Ringkasan Disertasi di Universitas Diponegoro, Semarang, 2017, hlm. 120.

7 Darpito Pudyastungkoro, "Wawasan Kebangsaan, Pancasila dan Persatuan Bangsa”, dalam Indonesia Satu, Indonesia Beda, Indonesia Bisa Membangun Bhinneka Tunggal Ika di Bumi Nusantara, ed. oleh Jimmy Oentoro (Jakarta: Kompas Gramedia, 2010), hlm. 34. 
mempersatukan manusia dari berbagai negara yang "diikat" dengan ideologinya masing-masing. Sebaliknya ideologi mempersatukan orang-orang dari berbagai agama. Ideologi juga berfungsi untuk mengatasi berbagai konflik atau ketegangan sosial. Dengan demikian ideologi juga berfungsi sebagai solidarity making. Ia juga mempunyai sifat futuristik, karena memberikan gambaran masa depan yang utopis. Nilai-nilai yang terkandung dalam ideologi merupakan nilai-nilai yang dicita-citakan bersama oleh para pengikutnya untuk diwujudkan. ${ }^{8}$ Dengan demikian tidak ada yang salah dengan Pancasila. Secara jujur harus diakui, bahwa di masa lampau Pancasila dijadikan alat politik untuk mempertahankan kekuasaan. ${ }^{9}$ Masa itu juga telah terjadi monopoli kebenaran dalam memaknai Pancasila, dan kemudian dimasyarakatkan melalui cara-cara yang indoktrinatif berwujud asas tunggal. ${ }^{10}$ Oleh sebab itu, agar tidak mengulang kesalahan yang sama, maka Pancasila melalui sila pertamanya harus ditempatkan guna menginspirasi tata hukum (ilmu hukum nasional) di bawahnya. Hal demikian seperti halnya yang termaktub dalam Pembukaan Undang Undang Dasar Negara Republik Indonesia (UUD NRI) 1945 yang menegaskan bahwa "kemerdekaan Indonesia adalah berkat rahmat Allah Yang Maha Kuasa”. Poin penting inilah yang selanjutnya menjadi pijakan lebih lanjut mengenai ilmu hukum nasional menuju biomijuridika yang bernafaskan sila pertama Pancasila dalam upayanya menggali sumber nilai ketuhanan, yang sejatinya

8 Pudyastungkoro, "Wawasan Kebangsaan, Pancasila dan Persatuan Bangsa”, hlm. 35 .

9 Pada masa Orde Baru, Pancasila dijadikan satu-satunya asas dan seluruh anggaran dasar dan anggaran rumah tangga organisasi kemasyarakatan harus berdasarkan Pancasila. Resistensi atas asas tunggal demikian berakibat dapat dibubarkannya organisasi massa yang tidak menerima Pancasila sebagai prinsip dasar maupun ideologi organisasi tersebut.

10 Asas tunggal diterapkan oleh Pemerintah Indonesia pada tahun 1985 melalui Undang-undang Nomor 8 Tahun 1985 tentang Organisasi Kemasyarakatan. Douglas E. Ramage, Politics in Indonesia: Democracy, Islam and the Ideology of Tolerance (New York: Routledge, 1995), hlm. 38 \& 191. Lihat juga Al Khanif, Hukum \& Kebebasan Beragama di Indonesia (Yogyakarta: LaksBang Mediatama, 2010), hlm. 206. Pasal 2 ayat (1) UU ini menegaskan bahwa "organisasi kemasyarakatan berasaskan Pancasila sebagai satu-satunya asas". 
sudah ada dalam berbagai ajaran agama yang hidup di Indonesia.

Merujuk pada rangkaian konsepsi nilai Pancasila sebagaimana diuraikan sebelumnya, maka ilmu hukum yang tidak berorientasi pada tiga pilar demikian, bukan merupakan ilmu hukum nasional. Mengingat uraian tersebut, wajarlah apabila Moeljatno pernah menyatakan bahwa "dalam negara kita yang berdasarkan Pancasila, dengan adanya sila ketuhanannya, maka tiap ilmu pengetahuan termasuk ilmu hukum yang tidak dibarengi dengan ilmu ketuhanan adalah tidaklengkap". Notohamidjojo pun sering menegaskan, bahwa "tanggung jawab jurist ialah merohanikan hukum, dan penilaian scientia yuridis harus mendalam dan mendasar pada conscientia (nilai kebenaran, keadilan, kejujuran, kasih sayang antar sesama)". ${ }^{11}$ Dengan demikian tidak ada "sekulerisasi" dalam pendidikan hukum dan ilmu hukum di Indonesia. Bertolak dari pandangan Moeljatno ${ }^{12}$ mengenai ketidaklengkapan ilmu pengetahuan yang tidak disertai ilmu ketuhanan, Barda mengemukakan bahwa ilmu hukum nasional Pancasila yang seyogianya dibangun adalah ilmu hukum nasional ber-Ketuhanan. Artinya, ilmu hukum nasional harus juga mengacu maupun menggali ilmu ketuhanan, baik yang ada di berbagai ajaran agama maupun dari ayat-ayat, tanda-tanda, contoh ciptaan Tuhan di alam, sebagaimana halnya dengan "biomimetika" (biomimetics). ${ }^{13}$

11 O. Notohamidjojo, Makna Negara Hukum (Jakarta: Badan Penerbit Kristen, 1967), hlm. 32.

12 Moeljatno, guru besar hukum pidana dan pernah menjadi Menteri Kehakiman, sewaktu menyampaikan kuliah umum di Universitas Islam Indonesia, Yogyakarta pada 12/9/1963 pernah menyatakan, "Dalam negara kita yang berdasarkan Pancasila, dengan adanya sila ketuhanannya, maka tiap ilmu pengetahuan yang tidak dibarengi dengan ilmu ketuhanan adalah tidak lengkap". Dengan demikian, seharusnya tidak ada sekularisasi dalam pendidikan hukum di Indonesia. Barda Nawawi Arief, Masalah Penegakan Hukum dan Kebijakan Hukum Pidana dalam Penanggulangan Kejahatan (Jakarta: Kencana Prenada Media Group, cetakan ketiga, 2010), hlm. 25.

13 Biomimetika merupakan cabang baru ilmu pengetahuan yang mencoba meniru mahluk hidup (a new branch of science that seeks to imitate living things), yaitu ilmu yang mempelajari rancangan di alam (hasil ciptaan/ilmu Allah), dan memecahkan masalah berdasarkan rancangan alam/Tuhan itu. Cabang ilmu pengetahuan ini telah secara luas diterapkan dalam dunia teknologi. Para begawan ilmu di bidang eksakta (astronom, fisikawan, ahli matematika, ahli aerodinamica, ahli biokimia, ahli biomolekuler, 
Berdasarkan kontemplasi mengenai Ilmu Tuhan yang coba diwujudkan oleh para ilmuwan menjadi disiplin biomimetika, Barda mengenalkan diksi biomijuridika sebagai disiplin ilmu hukum yang tidak sekuler. ${ }^{14}$ Dalam hal ini penulis mencoba menerjemahkan ilmu hukum yang tidak sekuler tersebut dengan mengaitkan kajiannya pada Sila Ketuhanan Yang Maha Esa. Oleh karenanya, penggalian ilmu hukum nasional diarahkan mengacu serta menggali ilmu ketuhanan, yang ada di berbagai ajaran agama di Indonesia.

Barda juga mengungkapkan beberapa rambu normatif hukum nasional yang secara eksplisit menyebutkan negara dan hukum harus berketuhanan. Di antaranya adalah ketentuan Konstitusi yang mengamanatkan "negara berdasar atas Ketuhanan Yang Maha Esa", ${ }^{15}$ ketentuan Undang-Undang Kekuasaan Kehakiman yang menyebutkan "peradilan negara menerapkan dan menegakkan hukum dan keadilan berdasarkan Pancasila" 16 dan "peradilan dilakukan 'Demi Keadilan Berdasarkan Ketuhanan Yang Maha Esa,", ${ }^{17}$ dan ketentuan Undang-Undang Kejaksaan yang mengatur "Demi keadilan dan kebenaran berdasarkan Ketuhanan Yang Maha Esa, jaksa melakukan penuntutan dengan keyakinan berdasarkan alat bukti yang sah" ${ }^{18}$ Berdasarkan berbagai ketentuan normatif tersebut, maka jelas bahwa pendidikan tinggi hukum dan ilmu hukum di Indonesia tidak seharusnya bersifat sekuler. Konsekuensinya, pendidikan tinggi hukum dan ilmu hukum nasional harus juga menggali ilmu hukum

biologiwan, dan sebagainya.) telah lama mengakui kecanggihan ilmu Tuhan. Arief, Pembangunan Sistem Hukum Nasional, hlm. 42-44. Lihat pula Harun Yahya, "Biomimetika: Mengambil Ilham dari Desain Mahluk Hidup", http://www.harunyahya.com/indo/artikel/071.htm.

14 Arief, Pembangunan Sistem Hukum Nasional, hlm. 34.

15 Pasal 29 ayat (1) Undang Undang Dasar Negara Republik Indonesia 1945.

16 Dalam Undang Undang Kekuasaan Kehakiman yang lama (Undang-undang Nomor 4 Tahun 2004), hal ini tercantum pada Pasal 3 ayat (2), sedangkan dalam UU yang baru (Undang-undang Nomor 48 Tahun 2009) terdapat pada Pasal 2 ayat (2).

17 Dalam Undang Undang Kekuasaan Kehakiman Tahun 2004, ketentuan ini terdapat pada Pasal 4 ayat (1), sedangkan dalam Undang-undang Kekuasaan Kehakiman Tahun 2009 tercantum pada Pasal 2 ayat (1).

18 Pasal 8 ayat (3) Undang Undang Nomor 16 Tahun 2004 tentang Kejaksaan Republik Indonesia. 


\section{Muhammad Rustamaji}

yang berketuhanan Yang Maha Esa. Ketika langkah demikian tidak ditempuh, maka bagaimana mungkin ketentuan yuridis-religius yang dipaparkan dalam berbagai norma tersebut dapat dipahami dan diterapkan dengan baik oleh para pembelajar dan para penegak hukum? Oleh karenanya, Barda sangat menyayangkan ketika dalam suatu negara yang ber-Ketuhanan Yang Maha Esa dan peradilannya dilakukan "Demi Keadilan Berdasarkan Ketuhanan Yang Maha Esa" tetapi mahasiswa hukum dan aparat penegak hukumnya hanya tahu tentang keadilan berdasarkan "tuntutanan undang-undang” dan tidak tahu tentang keadilan berdasarkan "tuntunan Tuhan".

Selain beragam rambu-rambu nasional sebagaimana diuraikan sebelumnya, mencermati kesimpulan Seminar Hukum Nasional ke-6 pada 1994, ditegaskan bahwa "perlu untuk dikembangkan gagasan mengenai kualitas pemberian keadilan (the dispension of justice) yang lebih cocok dengan sistem hukum Pancasila”. Kesimpulan demikian memberikan sinyalemen bahwa pendidikan tinggi hukum dan pembaruan ilmu hukum nasional harus menggali, mengkaji, dan mengajarkan kepada mahasiswa tentang apa yang dimaksud dengan "keadilan Pancasila". Berkenaan dengan konsep keadilan jenis baru yang berkaitan dengan ilmu hukum demikian, Barda mengutip pandangan Paul Scholten bahwa "ilmu hukum juga merupakan ilmu tentang keadilan”. Atas dasar demikian Barda berpendapat bahwa ilmu hukum Indonesia dengan demikian merupakan ilmu tentang keadilan Pancasila.

Pada kulminasi selanjutnya, Barda mengetengahkan bahwa keadilan Pancasila berarti keadilan berketuhanan, keadilan berkemanusiaan (humanistik), serta keadilan nasionalistik, demokratik dan berkeadilan sosial. Keadilan dalam konsepsi Pancasila demikian dapat diartikan bahwa keadilan yang ingin dicapai jelas bukanlah sekadar keadilan formal akan tetapi keadilan substantif atau keadilan materiel.

Kedalaman konsepsi keadilan Pancasila sebagai keadilan substantif inidapatdicontohkanketikamenguraihakikatindependensi peradilan. Barda mengemukakan bahwa hakikat atau nilai substansial dari independensi peradilan justru seharusnya bersumber dari 
keyakinan akan asas peradilan yang dilakukan "demi keadilan berdasarkan Ketuhanan Yang Maha Esa”. Kebebasan, kemerdekaan atau independensi substansial hanya ada pada orang yang merasa terikat atau tergantung pada kekuasaan Ilahiah (transendental), bukan kekuasaan yang lain. Lebih jauh Barda menjelaskan bahwa dengan menghayati serta menjiwai hakikat keadilan berdasar tuntunan Tuhan, barulah para penegak hukum utamanya hakim akan terbebas dari nilai dan kuasa subjektif, berupa hawa nafsu, kebencian golongan, ataupun hubungan kekerabatan yang bernuansa nepotisme maupun favoritisme. Pandangan transendental yang dikemukakan Barda tersebut ternyata berkesesuaian dengan tuntunan Tuhan dalam AlQuran Surah An Nissa', Al Maidah maupun Asy Syuura. Diwahyukan bahwa apabila kamu menghukum di antara manusia, maka hukumlah dengan adil. ${ }^{19}$ Bahkan setiap penegak hukum dituntun "jadilah kamu orang yang benar-benar menegakkan keadilan, menjadi saksi karena Allah, walaupun terhadap dirimu sendiri, ibu bapakmu dan kaum kerabatmu, janganlah kamu mengikuti hawa nafsumu karena ingin menyimpang dari kebenaran/keadilan". ${ }^{20}$ Diperintahkan pula kepada seluruh manusia tidak terkecuali kepada para penegak hukum untuk berbuat adil, "janganlah kebencianmu kepada suatu kaum atau golongan mendorong kamu untuk berlaku tidak adil" ${ }^{21}$ Berlaku adil demikian bahkan ditekankan wajib ditegakkan terhadap siapa saja, kendati terhadap orang yang tidak seagama. ${ }^{22}$ Konsep yang berasal dari tuntutan Tuhan inilah yang oleh Barda sudah seharusnya diintegrasikan dalam pembaruan ilmu hukum Indonesia. Ketika konsep yuridis-religius (demi keadilan berdasarkan ketuhanan Yang Maha Esa) demikian abai dilaksanakan, maka pembelajaran mengenai independensi peradilan misalnya, hanya manjadi formalitas sebatas irah-irah yang harus ada dalam suatu putusan, namun kering akan kajian substansinya.

Pada lingkup yang lebih luas, yaitu di tataran dunia, Barda

19 Al-Quran, Surat An-Nisaa' ayat (58).

20 Al-Quran, Surat An-Nisaa’ ayat (135).

21 Al-Quran, Surat Al-Maidah ayat (8).

22 Al-Quran, Surat Asy-Syuura ayat (15). 
juga menunjukkan bahwa saat ini terdapat kecenderungan untuk menemukan alternatif lain daripada sekadar berhukum berdasarkan undang-undang secara positivistik. Pergeseran pemikiran demikian dikemukakan Barda dengan mengutip pandangan Habiburrahman Khan yang mengetengahkan bahwa:

"People are busy doing research, holding seminar, international conference and writing books, trying to understand crime and its causes in order to control it. But the net result of all these efforts is to the contrary. Crimes marches on. I suggest that, just as in the $19^{\text {th }}$ century attention was diverted from the crime to its author-the criminal, we should go a step further and focus our attention, not on the criminal, but on to its author-society. We will have to change our sociopolitical and economic system that breeds criminals". ${ }^{23}$

Barda berpandangan sama atas pendapat Khan di atas yaitu dengan mengembangkan model konstruksi pemikiran hukum dan penegakan hukum integral-kontekstual. Diketengahkan oleh Barda bahwa seperti halnya perhatian serta pandangan pada abad ke-19 yang telah beralih dari "perbuatan" ke "orang", yaitu dari "kejahatan" ke si pembuatnya yaitu sang "penjahat", maka seharusnya sudah saatnya para pemikir hukum melangkah lebih lanjut dan memusatkan perhatian tidak pada sang penjahat, tetapi kepada si pembuatnya yaitu "masyarakat". ${ }^{24}$ Pemikiran demikian memiliki alur yang sama dengan hasil kongres PBB ke-6 (1980), ke-7 (1985) dan ke-10 (2000) yang mengungkap urgensi pengembangan pemikiran dalam upaya penanggulangan kejahatan sebagai produk masyarakat. Ide demikian melahirkan penanggulangan kejahatan secara integral yang menekankan pada upaya penanggulangan kausatif, yaitu menanggulangi sebab dan kondisi sejak di masyarakat. Salah satu wujud konkret gagasan integral demikian yaitu yang saat ini dikenal sebagai konsep restorative justice yang salah satunya ditempuh melalui mediasi penal. Bahkan konsep restorative justice demikian acapkali disebut sebagai the third way atau the third path yang menjadi jalan tengah

23 Habiburrahman Khan, "Prevention of Crime-It is Society Which Needs the Treatment and Not the Criminal”, Workshop The $33^{\text {rd }}$ Training Course UNAFEI No. 6, 1973, hlm. 127.

24 Arief, Pembangunan Sistem Hukum Nasional, hlm. 39. 
antara crime control justice dan due process mode ${ }^{25}$ dalam criminal justice system.

Melalui pengungkapan perkembangan di tataran dunia tersebut, sejatinya Barda juga berkeinginan untuk menegaskan bahwa kajian yang mendalam dan terus berkelanjutan mengenai pembaruan ilmu hukum nasional Pancasila, tidak mustahil juga dapat diusulkan kepada dunia sebagai salah satu model alternatif. Untuk itulah ketika Pancasila di dalamnya mengandung pilar religiusitas, maka pengembangan dan pembaruan ilmu hukum yang berdimensi ketuhanan sudah saatnya terus didalami.

Pada saat bersamaan, ketika Barda mencermati pandangan Harun Yahya dalam ulasan Kemilau Jagat Raya, yang salah satunya mengulas mengenai biomimetika (biomimetics) sebagai cabang ilmu baru yang coba meniru mahluk hidup, gagasan biomijuridika pada kajian ilmu hukum menjadi simpul gagasan beliau mengenai ilmu hukum Pancasila yang yuridis-religius. Oleh sebab itu, ketika biomimetika mempelajari rancangan di alam sebagai ciptaan Tuhan serta memecahkan masalah berdasarkan rancangan Tuhan untuk selanjutnya diterapkan dalam teknologi manusia, maka ilmu hukum juga harus melakukan hal yang sama, yaitu menerapkan hukum Tuhan dalam pembaruan ilmu hukum yang dikembangkannya. Oleh karenanya, ketika begawan ilmu Albert Einstein, dalam pergulatan pemikiran dan rancang-bangun ilmu yang dikajinya, pada sebuah kesempatan menyampaikan bahwa "ilmu tanpa agama adalah lumpuh, agama tanpa ilmu adalah buta”, Barda juga melontarkan gagasannya bahwa ilmu hukum tanpa agama (ilmu ketuhanan/ nilai-nilai religius) adalah tidak lengkap, timpang, dan bahkan berbahaya. $^{26}$

25 Herbert L. Packer, The Limit of The Criminal Sanction (Stanford, California: Stanford University Press, 1968), hlm. 17.

26 Barda Nawawi Arief, Pendekatan Keilmuan dan Pendekatan Religius dalam Rangka Optimalisasi dan Reformasi Penegakan Hukum (Pidana) di Indonesia (Semarang: Badan Penerbit Universitas Diponegoro, 2012), hlm. 56. Dalam pidato pengukuhan guru besarnya, Barda (Arief, Beberapa Aspek Pengembangan Ilmu Hukum Pidana, hlm. 59) juga mengungkapkan, "kajian ilmu hukum pidana yang semata-mata terfokus pada kajian norma dan 


\section{Muhammad Rustamaji}

Menelaah keseluruhan uraian tersebut, maka dapat ditarik suatu garis merah bahwa sebagai sebuah penanda atas suatu pemikiran di sektor hukum pidana, biomijuridika sejatinya mengajak setiap pembelajar hukum untuk merenung tentang apakah proses perjalanan panjang dari perkembangan penelitian, kajian keilmuan maupun pemikiran dari para ilmuwan serta guru besar itu begitu saja dapat diabaikan, dan layakkah ilmu, teori bahkan filsafat hukum pidana bersifat sekuler. Jika ilmu hukum mengandung di dalamnya ilmu "mengatur atau menata", bukankah ilmu Tuhan merupakan ilmu yang "Maha Mengatur dan Maha Menata?" Lalu bagaimana menggali serta membangun ilmu hukum pidana yang tidak sekuler (yang religius) atau bagaimana membangun biomijuridika seperti halnya biomimetika? ${ }^{27}$ Berbagai pertanyaan retoris inilah yang tentu memberi gambaran jelas bahwa pendidikan hukum dan ilmu hukum di Indonesia seharusnya tidak bersifat sekuler. Konsekuensinya, pendidikan tinggi hukum (PTH) dan ilmu hukum nasional (IHN) harus juga menggali/mengkaji ilmu hukum berketuhanan Yang Maha Esa. Apabila tidak, bagaimana mungkin ketentuan yuridisreligius di atas dapat dipahami dan diterapkan dengan baik. Sangatlah ironis, dalam negara berketuhanan Yang Maha Esa dan peradilannya dilakukan "Demi keadilan berdasarkan Ketuhanan Yang Maha Esa", tetapi mahasiswa hukum dan aparat penegak hukumnya hanya tahu tentang keadilan berdasarkan "tuntunan Undang-undang", tetapi tidak tahu tentang keadilan berdasarkan "tuntunan Tuhan".

\section{Urgensi dan Relevansi Biomijuridika}

Berdasarkan uraian sebelumnya, dapat diketahui bahwa pemikiran Biomijuridika diarahkan untuk mengkritik pendidikan tinggi hukum yang hanya berfokus dalam menyelenggarakan pendidikan hukum profesional. Pandangan Barda tersebut juga menyasar pada kurangnya perhatian pada tugas keilmuan (konsepsional akademik) dan tugas nasional (pembaruan hukum nasional) yang sudah seha-

terlepas dari kajian nilai, merupakan kajian yang parsial, timpang, dan bahkan dapat berbahaya”.

27 Arief, Pembangunan Sistem Hukum Nasional, hlm. 44. 
rusnya juga diemban oleh pendidikan tinggi hukum. Akan tetapi, ketika Boimijuridika diproyeksikan menjadi semacam model alternatif pembaruan hukum yang diusulkan kepada dunia, harus diakui hal demikian masih membuka ruang kritik dan dialektika ${ }^{28}$ yang sangat luas. Meminjam istilah Bernard Arief Sidharta mengenai pengembanan hukum, ${ }^{29}$ ruang-ruang dialektika demikian setidaknya berada pada dua ranah, yaitu ranah pengembanan hukum teoretis maupun pada ranah pengembanan hukum praktis.

Pada ranah pengembanan teoretis, sebagaimana dapat dilakukan susur galur beragam literatur, penekanan pentingnya nilai-nilai ketuhanan untuk diintegrasikan ke dalam pemikiran hukum sudah banyak dilontarkan oleh berbagai pakar. Oleh karenanya, pemikiran demikian jelas bukanlah sesuatu yang benar-benar baru. Walaupun Barda menyebutkan bahwa pemikiran Biomijuridika demikian terinspirasi dari pendapat Moeljatno dan Notohamidjojo, serta memperhatikan pandangan Habibur Rahman Khan, Albert Einstein

28 Dialektik (Dialektika) berasal dari kata dialog yang berarti komunikasi dua arah, istilah ini telah ada sejak masa yunani kuno ketika diintrodusir pemahaman bahwa segala sesuatu berubah (panta rei). Kemudian Hegel menyempurnakan konsep dialektika dan menyederhanakannya dengan memaknai dialektika ke dalam trilogi tesis, anti-tesis dan sintesis. Menurut Hegel tidak ada satu kebenaran yang absolut karena berlaku hukum dialektik, yang absolut hanyalah semangat revolusionernya (perubahan/ pertentangan atas tesis oleh anti-tesis menjadi sintesis). Menurut Tan Malaka dalam bukunya yang berjudul Madilog (Materialisme, Dialektika, Logika) dialektika mengandung 4 hal: waktu, pertentangan, timbal balik, dan seluk-beluk (pertalian). Tan Malaka, Madilog (Materialisme, Dialektika, Logika) (Jakarta:Narasi, cetakan kesembilan, 2017).

29 Istilah rechtsbeoefening dari Mauwissen yang dialihbahasakan oleh Bernard Arief Sidharta menjadi pengembanan hukum merupakan kegiatan manusia berkenaan dengan adanya dan berlakunya hukum di dalam masyarakat, yang meliputi kegiatan "membentuk, melaksanakan, menerapkan, menemukan, menafsirakan, meneliti dan secara sistematikal mempelajari dan mengajarkan hukum”. Pengembanan hukum dibedakan ke dalam pengembangan hukum praktikal dan pengembanan hukum teoretikal. Bernard Arief Sidharta, "Disiplin Hukum: Tentang Hubungan antara Ilmu Hukum, Teori Hukum, dan Filsafat Hukum (State of The Arts)", Pro Justitia, 20, 3 (2002), hlm. 3-15. Lihat juga, Bernard Arief Sidharta, Anton F. Susanto, Shidarta, Pengembanan Hukum Teoretis-Refleksi atas Konstelasi Disiplin Hukum (Bandung: LoGoz Publishing, cetakan kedua, 2015), hlm. 3-4. 
serta Harun Yahya, tentu saja masih terdapat pakar lain yang mengemukakan hal senada.

Kuntowijoyo misalnya, memaknai transendental dengan mendasarkan keimanan kepada Allah $^{30}$ dengan mengenalkan ilmu profetik, berupa humanisasi (takmuruna bil ma'ruf), liberasi (tanhauna anil munkar), dan transendensi (tu'minuna billah). ${ }^{31}$ Dalam hal ini, Kuntowijoyo mengemukakan bahwa unsurtransendensi harus menjadi dasar unsur yang lain dalam pengembangan ilmu dan peradaban manusia. Metode pengembangan ilmu dan agama menurut Kuntowijoyo itu disebut dengan istilah profetik yang mendasarkan pada Al-Quran dan Sunnah sebagai basis utama dari keseluruhan pengembangan ilmu pengetahuan. Al-Quran dan Sunnah dijadikan landasan bagi keseluruhan bangunan ilmu pengetahuan profetik, baik ilmu kealaman (ayat kauniyah) sebagai basis hukum-hukum alam, humaniora (ayat nafsiyah) sebagai basis makna, nilai dan kesadaran maupun ketuhanan (ayat qauliyah) sebagai basis hukum-hukum Tuhan. $^{32}$

Tokoh lain yang juga mendiskursuskan nilai ketuhanan dalam pemikiran hukum misalnya M. Amin Abdullah. Melalui paradigma interkoneksitas yang dikemukakan Amin, dialog antara metodologi filsafat dengan kalam diintegrasikan pada berbagai cabang ilmu pengetahuan. Amin menyebut diskursusnya ini dengan teantroposentrik-integralistik. Amin mengenalkan pula metode al ta'wil al ilmi dalam rangka memperoleh kebenaran ilmu (hukum), dengan menggunakan pendekatan Bayani, Irfani, dan Burhani. Pendekatan Bayani bekerja pada ranah menafsirkan teks. Realitas empiris dipahami dan ditafsirkan berdasarkan teks. Pendekatan Irfani menekankan pada pengalaman melalui penyinaran hakikat kebenaran Tuhan, yang bersumber pada pengalaman batin yang mendalam, otentik, dan fitri yang tidak terbantahkan oleh logika. Adapun validitas kebenaran dapat dirasakan secara langsung oleh

30 Al-Qur'an, Surat Ali Imron ayat 110.

31 Kuntowijoyo, Muslim Tanpa Masdjid (Bandung: Mizan, 2001), hlm. 364.

32 Kuntowijoyo, Islam Sebagai Ilmu: Epistemologi, Metodologi dan Etika (Jakarta: Teraju-PT. Mizan Publika,2004), hlm. 27. 
intuisi batin. Sedangkan pendekatan Burhani menekankan pada prinsip penggunaan logika yang melahirkan kesimpulan-kesimpulan secara pasti dan dapat dicerna secara logis. ${ }^{33}$

Pemikiran M. Amin Abdullah sejatinya mengadopsi pandangan Jasser Auda yang mengetengahkan bahwa hukum (Islam) dapat dikembangkan sebagai metodologi yang memadukan antara pendekatan sejarah dan pendekatan kefilsafatan. Pendekatan sejarah dengan memperhatikan dengan cermat perubahan dan pergerakan konsep, makna, dan interpretasi hukum pada era tradisional, modern dan postmodern. Sedangkan pendekatan filsafat dengan memanfaatkan teori sistem yang biasa digunakan dalam sains dengan mendasarkan enam fitur, yakni: kognisi (cognition), holistik (wholeness), keterbukaan (openness), interkonektifitas (interconnectedness), multidimensi (multidimensionality), dan selalu mengacu pada tujuan utama (purposefulness). ${ }^{34}$

Pada faset pengembanan teoretik ini, meskipun dapat dikatakan senada dalam meneguhkan pentingnya nilai-nilai ketuhanan untuk diintegrasikan ke dalam kajian dan pengembanan hukum, akan tetapi terdapat perbedaan yang dapat dianalisis. Jika Kuntowijoyo, M. Amin Abdullah, dan Jasser Auda berangkat dari kajian keislaman yang selanjutnya menyasar pada lapisan kajian hukum yang dalam, Barda justru menemukan beragam nilai keislaman setelah menyelami hukum dalam kaitannya dengan kandungan nilai sila pertama Pancasila. Kajian demikian meskipun akhirnya bertemu pada titik transenden bahwa ilmu hukum tidak seharusnya sekuler dan justru harus memiliki "akar tunggang” bermuatan nilai ilahiah, akan tetapi jalan yang ditempuh ternyata berbeda arah pada mulanya.

Berbeda dengan hukum profetik yang sejak semula menjejak kajian-kajian keislaman sebagai basis ontologi, epistemologi dan metodologinya, pemikiran mengenai biomijuridika memang masih

33 Absori, Kelik Wardiono, Saepul Rochman, Hukum Profetik: Kritik terhadap Paradigma Hukum Non-Sistematik (Yogyakarta: Genta Publishing, 2015), hlm. x.

34 M. Amin Abdullah, "Bangunan Baru Epistimologi Keilmuan Studi Hukum Islam dalam Merespon Globalisasi", Asy-Syir'ah: Jurnal Ilmu Syari'ah dan Hukum, 46, 2 (2012), hlm. 316. 


\section{Muhammad Rustamaji}

dirasakan tidak selengkap itu. Keunggulan pemikiran Barda justru dapat ditunjukkan dikarenakan kandungan nilai Pancasila yang berhasil dieksplorasi hingga ke tataran transenden dengan membandingkan hasil-hasil kajian, telaah para cendekiawan terdahulu, yang diselaraskan dengan studi perbandingan di berbagai negara dan hasilhasil kovenan internasional. Sisi transenden yang berhasil diekskavasi demikian, merupakan sesuatu yang sangat jarang terjadi pada pemikir hukum pidana yang acapkali dikungkung oleh asas legalitas yang serba lex scripta (tertulis), lex stricta (kaku), lex certa (jelas) dan lex preivea (tidak berlaku surut). Akan tetapi kejumudan pemikiran demikian justru tidak terjadi pada biomijuridika.

Namun demikian, pada paparan biomijuridika yang sudah disampaikan, harus diakui masih terdapat kekurangan yang harus disempurnakan kelindannya. Pada kulminasi ini, secara teoretik Barda hanya menjelaskan mengenai nilai keseimbangan Pancasila sebagai basis pembaruan ilmu hukum, yang berpilar nilai ketuhanan, nilai kemanusiaan, dan nilai kemasyarakatan. Barda masih sebatas mengajak setiap pembelajar hukum untuk merenung tentang apakah proses perjalanan panjang dari perkembangan penelitian, kajian keilmuan maupun pemikiran dari para ilmuwan serta guru besar itu begitu saja dapat diabaikan, dan layakkah ilmu, teori, bahkan filsafat hukum pidana bersifat sekuler. Ragam paparan Barda demikian selanjutnya hanya ditutup dengan sebaris kalimat retoris bahwa "Jika ilmu hukum mengandung di dalamnya ilmu mengatur atau menata, bukankah ilmu Tuhan merupakan ilmu yang Maha Mengatur dan Maha Menata $?^{35}$ Melalui pertanyaan retoris demikian, Beliau sejatinya masih meninggalkan "lahan garap" bagi para muridnya maupun kepada setiap pembelajar hukum untuk lebih dalam mengkaji kembali aspek-aspek pembaruan hukum, khususnya hukum pidana. Oleh karenanya, tidaklah mengherankan jika pemikiran biomijuridika demikian disebut baru sampai pada taraf himbauan moral bagi para pengemban hukum, baik pengemban hukum teoretis maupun pengemban hukum praktis (para penegak hukum).

35 Arief, Pembangunan Sistem Hukum Nasional, hlm. 44. 
Selanjutnya pada aras pengembanan hukum praktis, kritik terhadap biomijuridika dapat disajikan dalam beragam pertanyaan yang agaknya masih menyisakan banyak tanda tanya. Konsistensi konsep transendensi (nilai ketuhanan) dan imanensi (peristiwa konkret) pada biomijuridika dipandang masih belum digambarkan dengan jelas, misalnya bagaimana seharusnya para penegak hukum mengaplikasikan pemikiran biomijuridika demikian dalam penegakan hukum? Apakah hukum positif selalu harus dimaknai sebagai jembatan di antara transedensi dan imanensi? Apakah semua norma hukum positif harus selalu tunduk pada justifikasi atas nilainilai ketuhanan? Siapa yang bisa memastikan bahwa justifikasi tersebut benar-benar sudah sesuai dengan kehendak Tuhan? Apakah tidak dimungkinkan adanya kekeliruan tafsir atau perbedaan tafsir? Seberapa dalam para penegak hukum harus "dibebani” untuk memastikan tafsir-tafsir ini?

Terhadap beberapa pertanyaan kritis demikian, agaknya memang masih terdapat persoalan yang harus dijawab oleh pemikiran biomijuridika. Meskipun tidak secara gamblang menjawab seluruh permasalahan yang ada, Barda sejatinya pernah memberikan ilustrasi yang menarik berkait pengembanan hukum praktis ini. Terinspirasi dari ilustrasi menjalankan sebuah mobil pada suatu kosmologi beserta pengendara yang memegang lisensi (SIM) yang dimiliki sebagai simbol "ilmu mengemudi" yang dikuasainya, Barda Nawawi Arief menjelaskan pola hubungan mengenai dioperasionalisasikannya WvS (KUHP buatan Belanda) dalam konteks keindonesiaan oleh aparat negara. ${ }^{36}$ Dengan menggunakan pola pemikiran yang serupa, ternyata gambaran hubungan penegakan hukum, aparat penegak hukum, serta konteks negara hukum Indonesia, dapat dijelaskan pula korelasinya. Penggambaran demikian menjadi penting guna menentukan sikap untuk memosisikan Herziene Inladsch ReglementHIR (Hukum Acara buatan Belanda yang selanjutnya diubah menjadi KUHAP) yang notabene menjadi rule of the game dalam penegakan

36 Barda Nawawi Arief, Pendekatan Keilmuan dan Pendekatan Religius-Dalam Rangka Optimalisasi dan Reformasi Penegakan Hukum (Pidana) di Indonesia (Semarang: Badan Penerbit Universitas Diponegoro, 2012), hlm. 19-20. 


\section{Muhammad Rustamaji}

hukum, ketika "melaju” di dalam kosmologi Indonesia.

Sebagai sebuah konsep "asing”, Hukum Acara merupakan salah satu produk yang berkaitan dengan politik etis yang bersemboyan "geen exploitatie maar educatie" (tidak boleh lagi exploitasi, tetapi edukasi). Menukil apa yang dikemukakan oleh Soetandyo bahwa ketika pemerintah kolonial mulai menyelenggarakan pendidikan dengan gaya klasikal seperti yang dianut di Eropa, tak pelak lagi, sejalan dengan kebijakan Idenburg, program pendidikan untuk anak-anak pribumi dalam bidang kehukuman dan kehakiman ini nyata kalau diarahkan guna memperoleh rechtsamtenaren yang cakap dan berkepribadian kolonial yang secara khusus hendak melayani kebutuhan hukum orang-orang pribumi. ${ }^{37}$

Karakteristik hukum acara yang sudah melintasi periodisasi waktu yang panjang dan lahir di belahan dunia lain dengan sifat rigid (kaku) yang diperamnya, tentu saja memunculkan pertanyaan besar mengenai keterposisiannya ketika memasuki konfigurasi hukum dan konteks keindonesiaan. Pertanyaan mengenai apakah hukum acara yang dituangkan dalam HIR-KUHAP dapat berjalan begitu saja ketika memasuki suatu konteks kenegaraan, menjadi salah satu hal yang mengemuka. Dengan mengikuti ilustrasi yang sudah dikemukakan Barda sebelumnya, dapat dijelaskan bahwa ketika "mobil HIR-KUHAP" berkeinginan berjalan dengan baik, maka mobil HIR-KUHAP demikian harus dikendarai oleh pengemudi yang memiliki ilmu dan pengetahuan yang baik pula mengenai mobil yang dikendarainya, maupun segala aspek kewilayahan yang hendak dilaluinya. Artinya, ketika HIR-KUHAP memasuki kosmologi Indonesia, mau tidak mau para penegak hukum yang bertugas menegakkannya harus memahami secara benar apa yang dikandung HIR-KUHAP, maupun memahami dengan baik pula karakter hukum Indonesia sebagai "kontur jalan" yang akan dilewatinya. Penegak hukum yang memahami kandungan HIR-KUHAP dan

37 Soetandyo Wignjosoebroto, Dari Hukum Kolonial ke Hukum NasionalDinamika Sosial-Politik dalam Perkembangan Hukum di Indonesia (Jakarta: HuMa, Van Vollenhoven Institute, KITLV-Jakarta, Epistema Institute, 2014), hlm. 145 
karakter hukum Indonesia, dengan demikian dapat dikatakan sudah menguasasi "ilmu mengemudi" yang dipersyaratkan penegakannya dalam konteks Indonesia. Melalui ilmu mengemudi yang dikuasai dengan baik dan benar inilah yang selanjutnya mengantarkan "mobil" HIR-KUHAP melalui struktur kosmologi Indonesia dengan selamat dan mencapai tujuannya.

Mencermati pandangan Barda tersebut, diketahui bahwa urgensi kualitas keilmuan tidak hanya dimaksudkan semata-mata untuk meningkatkan kualitas pendidikan dan pengembangan ilmu hukum itu sendiri. Akan tetapi, kualitas keilmuan tersebutjuga untuk meningkatkan kualitas nilai dan produk dari proses penegakan hukum (in abstracto maupun in concreto). Bukankah kualitas, kesuksesan, kebahagiaan hidup (dunia dan akhirat), termasuk kualitas penegakan hukum di dunia, hanya dapat dicapai dengan ilmu? ${ }^{38}$ Aspek penguasaan keilmuan inilah yang semakin menunjukkan bahwa sisi manusia dan kemanusiaan aparat penegak hukum memegang peran penting ketika langkah pembaruan hendak dilaksanakan.

Oleh karenanya, Hukum Acara yang sejatinya sarat dengan keseimbangan yang serasi antara orientasi "penegakan dan perlindungan ketertiban masyarakat" di satu sisi dengan "kepentingan dan perlindungan hak-hak asasi manusia" 39 di sisi lain, tentu harus dijalankan oleh aparat penegak hukum yang memahami ilmu mengenai penegakan hukum dan HAM dengan sangat baik. Hal demikian dikatakan menjadi semacam prasyarat agar "kendaraan" yang bernama HIR-KUHAP demikian tidak menabrak "struktur jalan" kehidupan bersama, mengoyak "sparasi" tata kehidupan,

38 Barda Nawawi Arief menunjukan bahwa kedalaman penguasaan keilmuan tersebut bahkan harus bersumber dan berkesesuaian dengan ilmu ketuhanan, antara lain dinukilkan Hadist Nabi, man aroda dunya fa'alaihi bil 'ilmi, man arodal akhirota fa'alaikhi bil ilmi, wa man aroda huma fa'alaihi bil 'ilmi (Barang siapa menghendaki kebahagiaan hidup di dunia maka dengan ilmu, dan barang siapa menghendaki kebahagiaaan hidup di akhirat maka dengan ilmu, dan barang siapa menghendaki kebahagiaan keduanya maka dengan ilmu) (HR.Bukhari). Arief, Pendekatan Keilmuan dan Pendekatan Religius, hlm. 10-11.

39 M. Yahya Harahap, Pembahasan Permasalahan dan Penerapan KUHAP (Penyidikan dan Penuntutan) (Jakarta: Sinar Grafika, 2003), hlm. 38. 


\section{Muhammad Rustamaji}

maupun melanggar "rambu-rambu" komunalitas hidup berbangsa. Karena, apabila yang terjadi adalah beragam benturan dalam mengaplikasikan Hukum Acara, tentu akan membawa ekses negatif bagi sang "pengendara". Pelanggaran atas Hukum Acara segera saja akan memicu sentimen negatif bagi aparat penegak hukum, bahkan "merendahkan sang pengemudi" karena dianggap tidak cakap dalam mengendarai kendaraannya. Artinya, sang penegak hukum tidak menguasai ilmu dan tidak memiliki kapabilitas yang harus dipahaminya dengan baik ketika melakukan penegakan hukum yang notabene berbasis keseimbangan penegakan hukum dan HAM. Penguasaan keilmuan yang tidak memadai demikian, pada konteks yang lebih luas dapat semakin memperburuk penilaian masyarakat dunia atas Indonesia sebagai suatu bangsa atas konsepsi kemanusiaan yang diperamnya. Contoh kasus konkrit, mengenai meninggalnya Siyono dalam proses penegakan hukum, atau terbunuhnya aktivis HAM Munir, tentu dapat dikaji kandungan hikmah filosofisnya dalam kerangka aplikasi penegakan hukum di Indonesia.

Mencermati gambaran ekses buruk yang dapat timbul akibat tidak memadainya keilmuan mengenai penegakan hukum dan HAM, serta luasan cakupan dan besarnya dukungan akan pentingnya penegakan hukum dan HAM, maka aspek yang selanjutnya harus dipikirkan adalah mengenai sumber daya manusia yang menjalankan penegakan hukum dan HAM dimaksud. Kualifikasi dan kompetensi pengemban hukum praktis yang biasa-biasa saja, tentu tidak akan mampu menjawab tuntutan dunia agar pemenuhan dan perlindungan HAM terlaksana dengan baik. Oleh karenanya, diperlukan kualitas dan kuantitas personal penegak hukum yang tinggi guna mengemban tanggungjawab reinput pengembalian ekses tindak pidana ke jalan yang benar. Sehingga pada kulminasi tertentu officium nobile sebagai predikat mulia bagi semua aparat penegak hukum, dapat diwujudkan dalam bentuk yang tidak hanya sekedar wacana dan utopia.

Pada konteks pemenuhan kualifikasi sumber daya manusia penegakhukumdemikian, biomijuridika agaknya belum memaparnya dengan jelas. Justru gagasan mengenai prophetic intelligence (PI) dalam menentukan kualifikasi penegak hukum yang memahami HAM, 
tampaknya perlu dipertimbangkan sebagai masukan bagi konsep pemikiran biomijuridika. Penggambaran PI mengenai penegak hukum yang memahami HAM dengan kualifikasi tinggi tersebut menekankan pada aspek manusia sebagai fokus kajian. Kemampuan mentransformasikan diri untuk berani melakukan rule breaking ${ }^{40}$ mensyaratkan apa yang disebut PI tersebut. Kecerdasan kenabian inilah yang memandu sekaligus memberikan keberanian holistik bagi para penegak hukum ketika mengemban hukum praktis ala biomijuridika.

Mencermati perkembangan kekinian, disiplin psikologi mengembangkan prophetic intelligence atau kecerdasan kenabian, sebagai pendekatan menyeluruh dari pendekatan kecerdasan yang sebelumnya ada. PI inilah yang memandu cognitive intelligence, emotional intelligence, adversity intelligence, dan spiritual intelligence. ${ }^{41}$ Pembenaman PI dalam kemauan dan kemampuan mentransformasi diri inilah yang dimaksud dengan kualifikasi tinggi dalam tipologi penegak hukum yang sejatinya sebangun dengan pemikiran biomijuridika.

Terhadap hasil temuan PI demikian, biomijuridika atau bahkan kajian hukum sangat berkepentingan "meminjam" konsep kecerdasan kenabian ini guna mengatasi krisis hukum maupun kegamangan pemenuhan penegakan hukum dan perlindungan HAM yang terjadi. Terlebih ketika optik krisis tersebut diarahkan pada moralitas ${ }^{42}$ para penegak hukum. Dapat dikemukakan bahwa kecerdasan kenabian merupakan kemampuan seseorang untuk mentranformasikan dirinya dalam interaksi, sosialisasi dan adaptasi dengan lingkungan vertikal dan horizontal. Konsepsi dualistik lahiriah dan batiniah,

40 Satjipto Rahardjo, Hukum Progresif; Sebuah Sintesa Hukum Indonesia (Yogyakarta: Genta Publishing, 2009), hlm. 61-62.

41 M. Syamsudin, Konstruksi Baru Budaya Hukum Hakim Berbasis Hukum Progresif (Jakarta: Kencana, 2012), hlm. 262.

42 Operasi Tangkap Tangan (OTT) terhadap Jaksa AF beserta barang bukti uang suap Rp1,5 Milyar oleh Tim Sapu Bersih Pungutan Liar (Saber Pungli) Kejaksaan Agung, merupakan contoh kasus terbaru gambaran moralitas penegak hukum yang masih saja digerogoti 'naluri lapar' yang oleh Konrad Lorenz (1969) menumbuhkan mental menerabas. Achmad Fauzi, "Badai Suap Korp Adhyaksa”, Jawa Pos, 30/11/2016. 
kehidupan duniawi dan ukhrowi, diambil untuk dipahami manfaat dan hikmahnya. Pada sisi inilah pengejawantahan irah-irah "Demi Keadilan Berdasarkan Ketuhanan Yang Maha Esa” yang selanjutnya diimplementasikan dalam sistem penegakan hukum, menemukan momentumnya untuk dicamkan kembali sebagaimana harapan Barda pada uraian sebelumnya.

Pada prinsipnya, setiap orang dapat meraih kecerdasan kenabian, dengan syarat mau melakukan transformasi diri. Khusus bagi penegak hukum, transformasi diri ini mencakup penyadaran, penemuan, dan pengembangan diri dengan mengamalkan, menginsyafi serta menghayati sifat prinsip kejujuran (sidiq), dapat dipercaya (amanah), terbuka (tabliq), dan cerdas (fatonah). Transformasi diri para penegak hukum yang menepati jalan Ilahi demikian, dimaksudkan untuk membuka peluang seluas-luasnya untuk mendapatkan bimbingan Allah, yaitu khoirunnas anfauhum linnas ketika menjalankan tugas mulia sebagai penegak hukum. ${ }^{43}$

Pada titik "transformasi diri para penegak hukum" ini, pemikiran biomijuridika sejatinya berbagi ruang dengan pemikiran Hukum Progresif. Ketika transformasi diri telah dilakukan, maka rule breaking menjadi sikap tindak yang tampak. Biomijuridika maupun hukum progresif menegaskan tawaran yang sama dalam pendekatan penegakan hukum yang bukan sebatas berbasis logosentrisme teks hukum yang dikedepankan. Logosentrisme sebagai kecenderungan sistem pemikiran yang mencari legitimasinya dengan mengacu pada dalil-dalil kebenaran universal atau jaminan makna sentral dan orisinal, ${ }^{44}$ menjadi penghalang utama yang sudah saatnya harus mulai

43 Dengan menepati jalan Ilahi melalui upaya transformasi diri dan munajad dengan ragam ibadah kepadaNya, serangkaian langkah demikian semoga menghadirkan keridhoan sehingga Allah berkenan membimbing hambaNya menjadi sebaik-baik manusia yaitu manusia yang memberi manfaat bagi sesamanya. Muhammad Rustamaji, "Mengggali Akar Transendensi Pancasila, Menuju Ilmu Hukum Berketuhanan Yang Masa Esa”, dalam Transendensi Hukum Prospek dan Implementasi, ed. Absori, Kelik Wardiono, Shidarta, dan Aan Asphianto (Yogyakarta: Genta Publishing \& Program Doktor Ilmu Hukum Sekolah Pascasarjana UMS, 2017), hlm. 394-395.

44 Anthon F. Susanto, Ilmu Hukum Non Sistematik: Fondasi Filsafat Pengembangan Ilmu Hukum Indonesia (Yogyakarta: Genta Publishing, 2010), hlm. xii. 
ditinggalkan dalam rangkaian transformasi diri sang penegak hukum. Pada faset inilah ditemukan apa yang ada di balik setiap tindakan penegakanhukum, maupununtukmasyarakatpadaumumnya sebagai pemenuhan konsep "orang yang bermanfaat bagi sesamanya”. Para penegak hukum dengan transformasi diri demikian akan membawa penyadaran bahwa penegakan hukum harus dilaksanakan dengan cara yang baik, agar tujuan penegakan hukum yang sejatinya baik dapat mencapai titik tujuan akhirnya, yaitu keadilan, kemanfaatan dan kepastian hukum. Pada kulminasi inilah pemikiran biomijuridika diharapkan lebih detail untuk memperluas dan sekaligus mengasah multiple intelligence para penegak hukum yang dipandu prophetic intelligence. Sehingga ketika palu diketukkan dengan irah-irah "Demi Keadilan Berdasarkan Ketuhanan Yang Maha Esa", upaya penegakan hukum dengan segenap tahapan yang telah dilaluinya menjadi harapan selanjutnya yang menunjukkan sebuah upaya holistik dalam rangkaian penegakkan keadilan hukum dan pemenuhan serta perlindungan HAM yang dapat dipertanggungjawabkan secara vertikal kepada Tuhan Yang Maha Esa, dan sekaligus secara horizontal kepada semua manusia. Dengan demikian, penegakan hukum pada semua tahap atau tingkat pemeriksaan yang menerapkan biomijuridika harus dapat dieksplanasi secara moral-etik terhadap permasalahan atau kasus yang dihadapi. Sebagai sebuah penglihatan etik, maka ukuran tentang "yang benar", "yang baik", dan "yang tepat" mengenai penegakan hukum disorot melalui perspektif etika deontologis (etis berdasar prinsip objektif universal), perspektif etika teleologis (etis berdasar tujuan), dan perspektif etika situasi atau kontekstual (etik berdasar konteksnya). ${ }^{45}$

\section{E. Kesimpulan}

Artikel ini menyimpulkan, pertama, biomijuridika merupakan pemikiran hukum dari Barda Nawawi Arief yang berintikan bahwa ilmu hukum pidana nasional harus mengacu dan menggali ilmu ketuhanan,

45 Bernard L. Tanya, Penegakan Hukum dalam Terang Etika (Yogyakarta: Genta Publishing, 2011), hlm. 12-22. 
baik yang ada di berbagai ajaran agama maupun dari ayat-ayat, tanda-tanda, dan contoh ciptaan Tuhan di alam. Ilmu hukum pidana nasional, dengan demikian merupakan ilmu hukum pidana yang berketuhanan. Keharusan demikian dikarenakan bahwa kehidupan berbangsa dan bernegara Indonesia didasarkan pada Pancasila, yang dalam kehidupan berhukum berarti mesti, salah satunya, didasarkan pada "Ketuhanan Yang Maha Esa”. Dalam negara yang berketuhanan dan peradilannya dilakukan "Demi Keadilan Berdasarkan Ketuhanan Yang Maha Esa”, maka pembangunan dan penegakan hukum tidak boleh hanya berdasarkan "tuntunan Undang-undang", tetapi juga mesti berdasarkan "tuntunan Ilahi Robbi”. Kedua, pemikiran hukum biomijuridika dari Barda tampaknya masih menyisakan ruang diskursus yang agaknya belum dijawab dengan tuntas, yaitu ketika konsep ini diajukan sebagai salah satu model alternatif pembaruan hukum. Kritik demikian khususnya dapat dicermati pada faset pengembanan hukum teoretis dan pengembanan hukum praktis. Oleh karenaya, untuk sampai pada suatu titik pencerahan bahwa ilmu hukum mengandung di dalamnya ilmu "mengatur atau menata” yang selaras dengan ajaran "Tuhan yang Maha Mengatur dan Maha Menata”, maka konsep biomijuridika yang telah dimulai Barda harus terus diulas, dikembangkan, dan didiskursuskan aspek pengembananya.

\section{Daftar Pustaka}

\section{Artikel/Buku/Laporan}

Abdullah, M. Amin. "Bangunan Baru Epistemologi Keilmuan Studi Hukum Islam dalam Merespon Globalisasi”. Asy-Syir'ah: Jurnal Ilmu Syari'ah dan Hukum, 46, 2 (2012): 315-368. DOI: 10.14421/ asy-syir'ah.2012.\%25x

Absori, Kelik Wardiono, dan Saepul Rochman. Hukum Profetik: Kritik terhadap Paradigma Hukum Non-Sistematik. Yogyakarta: Genta Publishing, 2015.

Al Khanif. Hukum \& Kebebasan Beragama di Indonesia. Yogyakarta: LaksBang Mediatama, 2010. 
Arief, Barda Nawawi. Beberapa Aspek Pengembangan Ilmu Hukum Pidana (Menyongsong Generasi Baru Hukum Pidana Indonesia). Semarang: Pustaka Magister, 2011.

Arief, Barda Nawawi. Masalah Penegakan Hukum dan Kebijakan Hukum Pidana dalam Penanggulangan Kejahatan. Jakarta: Kencana Prenada Media Group, 2010.

Arief, Barda Nawawi. Pembangunan Sistem Hukum Nasional (Indonesia). Semarang: Pustaka Magister, 2012.

Arief, Barda Nawawi. Pendekatan Keilmuan dan Pendekatan Religius dalam Rangka Optimalisasi dan Reformasi Penegakan Hukum (Pidana) di Indonesia. Semarang: Badan Penerbit Universitas Diponegoro, 2012.

Fauzi, Achmad. "Badai Suap Korp Adhyaksa”. Jawa Pos, 30/11/2016. Harahap, M. Yahya. Pembahasan Permasalahan dan Penerapan KUHAP (Penyidikan dan Penuntutan). Jakarta: Sinar Grafika, 2003.

Https://bardanawawi.wordpress.com/riwayat-hidup/. Diakses $20 / 7 / 2019$.

Khan, Habiburrahman. "Prevention of Crime-It is Society Which Needs the Treatment and Not the Criminal”. Makalah Workshop pada the $33^{\text {rd }}$ Training Course UNAFEI No. 6, 1973.

Kuntowijoyo. Muslim Tanpa Masdjid. Bandung: Mizan, 2001.

Kuntowijoyo. Islam Sebagai Ilmu: Epistemologi, Metodologi dan Etika. Jakarta: Teraju-PT. Mizan Publika, 2004.

Malaka, Tan. Madilog (Materialisme, Dialektika, Logika). Jakarta: Narasi, 2017.

Moeljatno. "Sari Kuliah Umum”, UII Yogyakarta, 12/9/1963.

Notohamidjojo, O. Makna Negara Hukum. Jakarta: Badan Penerbit Kristen, 1967.

Oentoro, Jimmy. Indonesia Satu, Indonesia Beda, Indonesia Bisa 'Membangun Bhinneka Tunggal Ika di Bumi Nusantara'. Jakarta: Kompas Gramedia, 2010.

Packer, Herbert L. The Limit of the Criminal Sanction. Stanford, California: Stanford University Press, 1968.

Pudyastungkoro, Darpito. "Wawasan Kebangsaan, Pancasila dan Persatuan Bangsa". Dalam Indonesia Satu, Indonesia 
Beda, Indonesia Bisa Membangun Bhinneka Tunggal Ika di Bumi Nusantara', disunting oleh Jimmy Oentoro, 33-54. Jakarta: Kompas Gramedia, 2010.

Ramage, Douglas E. Politics in Indonesia: Democracy, Islam and the Ideology of Tolerance. New York: Routledge, 1995.

Rahardjo, Satjipto. Hukum Progresif; Sebuah Sintesa Hukum Indonesia.

Yogyakarta: Genta Publishing, 2009.

Rustamaji, Muhammad. "Pembaruan Hukum terhadap Formulasi

Asas Praduga Tidak Bersalah dalam Konteks Keindonesiaan (Kajian Norma dan Nilai)". Ringkasan Disertasi, Universitas Diponegoro, Semarang, 2017.

Rustamaji, Muhammad. "Mengggali Akar Transendensi Pancasila,

Menuju Ilmu Hukum Berketuhanan Yang Masa Esa”. Dalam

Transendensi Hukum: Prospek dan Implementasi, diedit oleh Absori, Kelik Wardiono, Shidarta, dan Aan Asphianto, 381-396.

Yogyakarta: Genta Publishing \& Program Doktor Ilmu Hukum Sekolah Pascasarjana UMS, 2017.

Sidharta, Bernard Arief. "Disiplin Hukum: Tentang Hubungan antara Ilmu Hukum, Teori Hukum, dan Filsafat Hukum (State of The Arts)". Pro Justitia, 20, 3 (2002): 3-15.

Sidharta, Bernard Arief, Anton F. Susanto, dan Shidarta. Pengembanan

Hukum Teoretis-Refleksi atas Konstelasi Disiplin Hukum. Bandung:

LoGoz Publishing, cetakan kedua, 2015.

Susanto, Anthon F. Ilmu Hukum Non Sistematik: Fondasi Filsafat

Pengembangan Ilmu Hukum Indonesia. Yogyakarta: Genta Publishing, 2010.

Syamsudin, M. Konstruksi Baru Budaya Hukum Hakim Berbasis Hukum Progresif. Jakarta: Kencana, 2012.

Tanya, Bernard L. Penegakan Hukum dalam Terang Etika. Yogyakarta:

Genta Publishing, 2011.

Wignjosoebroto, Soetandyo. Dari Hukum Kolonial ke Hukum Nasional:

Dinamika Sosial-Politik dalam Perkembangan Hukum di Indonesia.

Jakarta: HuMa, Van Vollenhoven Institute, KITLV-Jakarta, Epistema Institute, 2014.

Yahya, Harun. Biomimetika: Mengambil Iham dari Desain Mahluk 
Hidup. http:/ / www.harunyahya.com/indo/artikel/071.htm.

\section{Peraturan Hukum}

Herzien Inlandsch Reglement (HIR) (S.1941-44)

Republik Indonesia. Undang Undang Dasar Negara Republik Indonesia 1945.

Republik Indonesia. Undang-undang Nomor 8 Tahun 1985 tentang Organisasi Kemasyarakatan.

Republik Indonesia. Undang-undang Nomor 8 Tahun 1981 tentang Hukum Acara Pidana (KUHAP).

Republik Indonesia. Undang-undang Nomor 4 Tahun 2004 tentang Kekuasaan Kehakiman.

Republik Indonesia. Undang-undang Nomor 16 Tahun 2004 tentang Kejaksaan Republik Indonesia.

Republik Indonesia. Undang-undang Nomor 48 Tahun 2009 tentang Kekuasaan Kehakiman. 